\title{
ラリー車用バケットシートの機能条件
}

\section{○高木大輔、上野義雪 (千葉工業大学)}

A Study on the Functional Condition of Carseat for Rally Competition

OTakagi Daisuke, Ueno Yoshiyuki(Chiba Institute of Technology)

\section{1.目的}

一般的な乗用車を使用するモータースポーツ競 技には短時間のタイムトライアル形式で行われる 【ダートトライアル」競技と、長距離長時間の走 行を強いられる「ラリー」競技がある。競技車両 の操作性を向上させる要素をもつ「バケットシー 卜」は、使用者によっては不具合が生じる。そこ で、本研究ではシートの条件によりハンドルの操 作性や長時間走行に扔ける疲労、被験者の体型の 違いによるシートの不具合点の違い等について人 間工学的立場加調査と実験を行う。

\section{2.方法}

\section{1.アンケート調査}

モータースポーツの経験者にアンケート調査を 行い、バケットシートについて使用上のメリット や不具合点を明らかにする。（成人男子 30 名）

\section{2.静的実験}

使用するシートは、ノーマルシートとバケット シートの 2 種類とし、いづれも形状が異なる。

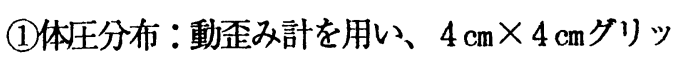
ド上を一点ずつ着座時の圧力を調べる。

(2)最終安定姿势の計測 : 石高包帯、未着座、着座 時のクッションの沈み具合を調べる。被験者は

- No.1 身長 $176 \mathrm{~cm}$ 体重 $80 \mathrm{~kg}$ 運転歴 4 年

- №.2 身長 $165 \mathrm{~cm}$ 体重 $52 \mathrm{~kg}$ 運転歴 2 年 の成人男子 2 名とする。 実験は実験室にシートを用意して行う。

(表1サンプルシート参照)

\section{3 動的実験（実車走行実験)}

（1）長時間走行 (ラリー実験)

(1)千葉工大 $\rightarrow$ 那須高原の往復 $340 \mathrm{~km}$ 姿勢変化の回数、しびれ・痛みの部位を調査 (2)舗装林道 (X市舗装林道) 走行時間約 3 分 身体のふれ幅をビデオで撮影

（2）短時間走行（ダートトライアル実験） 専用コースにて実験を行う。

身体のふれ幅をビデオで撮影 走行時間約 2 分

\section{3.漹作の提案と評価}

評価の高いシートBについて㮏まわりと脇腹あ たりのサポート性を強くした条件でシートCを試 作した。この試作シートについて走行実験を行っ た結果、身体のふれが少なくなることを確認する ことができた。（図4参照）

\section{4.结果}

(1)アンケート調査

運転歴と自動車の運転による腰痛経験の有無 は、当初の予想では運転歴の長い人ほど自動車の 連転か原因で腰痛になると思われたが、運転歴が 1、2年の人でも腰痛経験者かれた。れは、シー トとしての機能を果たさないバケットシートを使 用した結果だと思われる。

(2)体压分布

座面、背もたれともに支持条件の良いシート は、シートBであった。被験者によっては大腿部 寒側に圧迫がみられた。（表 1 体圧分布参照） 
(3)最終安定姿勢

座面、背もたれともに支持条件の良いシート

は、シートBであった。体重の軽い被験者の方が 座骨結節点付近の沈み量が大きく、逆に体重の重 い被験者の方が沈み量が少なく座骨結節点付近の 沈み込みは明確に現れなかった。（図1参照)

(4)長時間走行（ラリー実験(1)）

(1)姿勢、動作の変化回数

運転開始直後、シートBは、シートAに比へ動作 を始める時間は30分ほど遅くなるが、2脚とも同 じような傾向を示す結果となった。（図2参照）

(2)痛み・しびれの訴え

シートの支持条件に影響する痛み・しびれの訴 えの回数をみると、変化の少ないシートはシート Bであったが被険者によっては、部分的な痛みの 訴えがあった。（図3参照）

(4)ラリー実験2、ダートトライアル実験

シートAは、シートフレームの剛性が低くシー

表-1 サンプルシートと体圧分布の計泟洁果

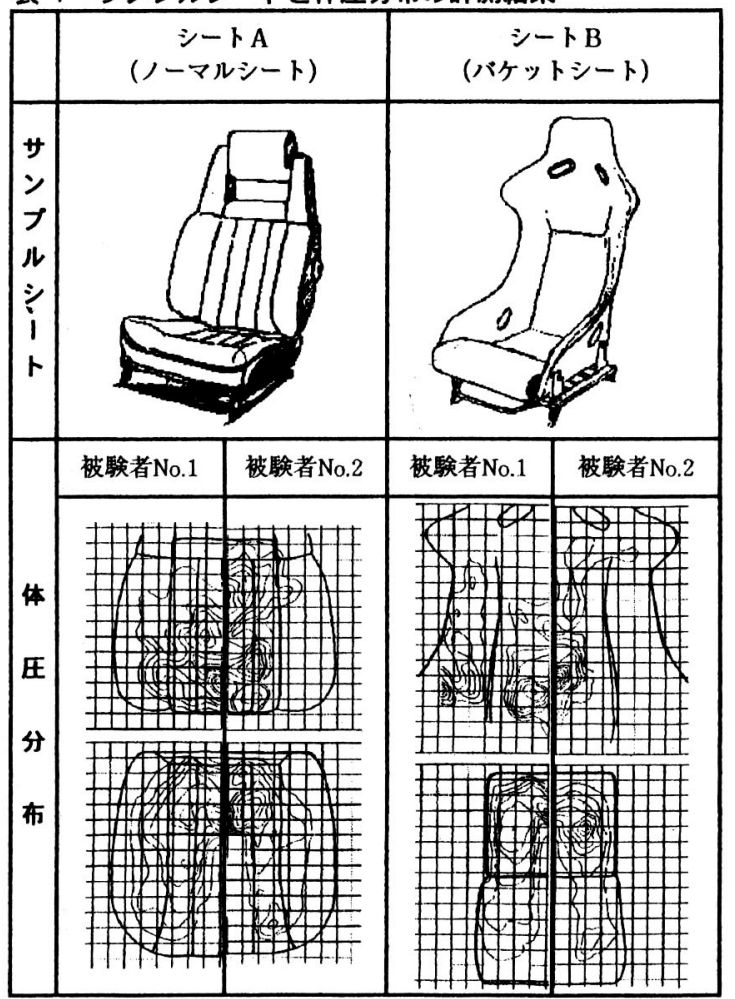

トが変形し、安定した姿勢で操作を行うことがで きなかった。シートBでは、下肢や上体の左右に ふれない様に配慮されているため膝の左右のふれ は少なかったが、改善の余地があると思われる。

\section{5.考察}

長時間走行における疲労の軽滅は座面、背もた れの前後方向の支持条件の良否により左右され、 またモータースポーツ走行においてはシートの左 右方向の支持力、特に㑡壁、脇腹の支持、大腿部 前端部における支持力を高めることが必要であ る。本研究では体型と疲労の関係について具体的 に明らかにすることができなかったので今後の検 討が必要であると考える。
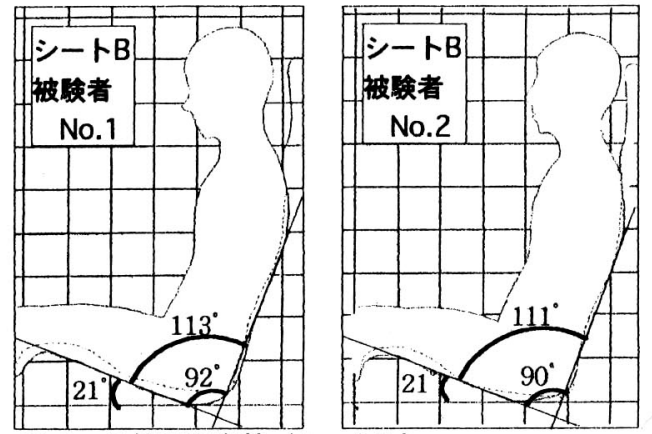

图-1 最終安定姿杽 (シートB)

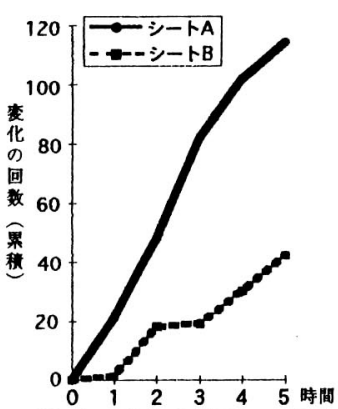

図-2 功作と姿勢の变化
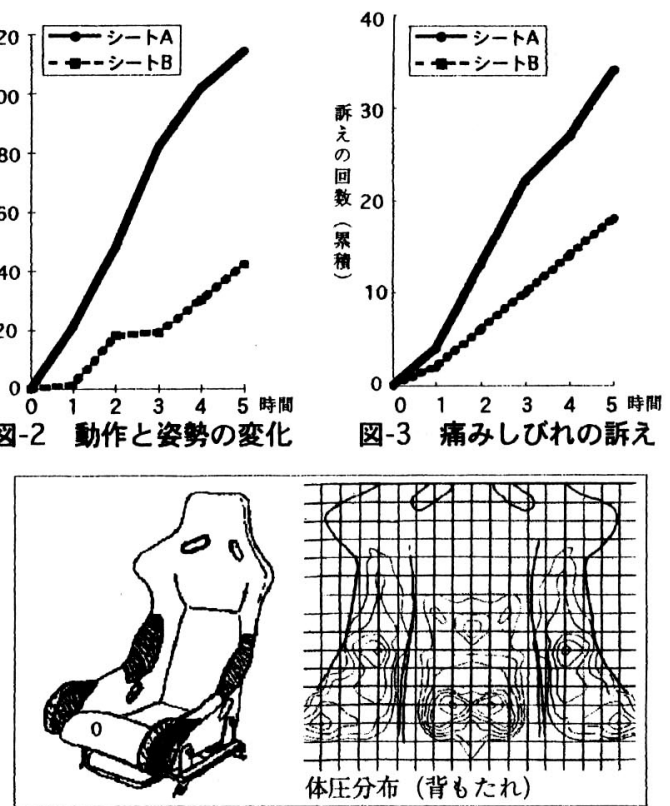

图-4 シートC（拭作） 